\title{
On the Babylonian Origin of Symbolic Logic
}

\author{
Andrew Schumann \\ University of Information Technology and Management in Rzeszow, \\ Rzeszow, Poland
}

e-mail: andrew.schumann@gmail.com

\begin{abstract}
The logical reasoning first appeared within the Babylonian legal tradition established by the Sumerians in the law codes which were first over the world: Ur-Nammu (ca. 2047 - 2030 B.C.); Lipit-Ishtar (ca. 1900 1850 B.C.), and later by their successors, the Akkadians: Hammurabi (1728 - 1686 B.C.). In these codes the casuistic law formulation began first to be used: "If/when (Akkadian: šumma) this or that occurs, this or that must be done" allowed the Akkadians to build up a theory of logical connectives: "... or...", "... and...", "if..., then...", "not..." that must have been applied in their jurisprudence. So, a trial decision looked like an inference by modus pones and modus tollens or by other logical rules from (i) some facts and (ii) an appropriate article in the law code represented by an ever true implication. The law code was announced by erecting a stele with the code or by engraving the code on a stone wall. It was considered a set of axioms announced for all. Then the trial decisions are regarded as claims logically inferred from the law code on the stones. The only law code of the Greeks that was excavated is the Code of Gortyn (Crete, the $5^{\text {th }}$ century B.C.). It is so similar to the Babylonian codes by its law formulations; therefore, we can suppose that the Greeks developed their codes under a direct influence of the Semitic legal tradition: the code was represented as the words of the stele and the court was a logic application from these words. In this way the Greek logic was established within a Babylonian legal tradition, as well. Hence, we can conclude that, first, logic appeared in Babylonia and, second, it appeared within a unique legal tradition where all trial decisions must have been transparent, obvious, and provable. The symbolic logic appeared first not in Greece, but in Mesopotamia and this tradition was grounded in the Sumerian/Akkadian jurisprudence.

Keywords: symbolic logic, Babylonian legal tradition, Hammurabi, Greek logic, Law Code of Gortyn, general, particular, modus pones, modus tollens.
\end{abstract}




\section{Introduction}

Conventionally, Aristotle (384 - 322 B.C.) is considered a father of symbolic logic. In this paper, I try to show that this statement is false, since the Greek logic (the Aristotelian logic as well as the Stoic one) was based on a Sumerian-Akkadian legal hermeneutics. So, the origin of symbolic logic should have been connected to establishing a logical tradition of the Sumerian-Akkadian jurisprudence at first.

The legal tradition of the Talmud is a direct continuation of the Babylonian tradition. The majority of the legal terminology in Mišnahitic Hebrew as well as in Talmudic Aramaic was taken from Akkadian. The Akkadian root words were considered indicators of a high-level literary language. For example, the Akkadian term of alaktu to denote 'a way' or even 'a spiritual road,' most probably, became a root word for the Hebrew term of halakah (Hebrew: "way," "law"). The point is that, according to the Bible and the Talmud, the Jewish community after the Babylonian captivity (i.e. since ca. 587 B.C.) enjoyed a fairly high status in Babylonia, e.g. "Mordecai sat in the king's gate" (Esther 2:21). We can assume that many Judahites served as judges or scribes at the house of the Achaemenid kings and, therefore, they learned the Akkadian-Aramaic legal tradition well and, then, they became "Talmudists."

The relative law formulations ("if a crime, then a punishment") allowed the Sumerians and Akkadians to differ general cases/notions from particular cases/notions and to use a naïve set theory. The analysis of Old-Babylonian and New-Babylonian business correspondence and trial records shows us many examples of difficult logical schemata as results of applications of some inference rules to law codes. The main idea of Babylonian trial was that any trial must be final in problem decision and its verdict must be complete and be inferred from the list of arguments (facts and documents): "If facts and documents, then a trial verdict." In case the set of arguments is not complete for inferring a final decision, the court takes a conditional verdict: "If facts and documents, then if an additional document that is missing, then a trial verdict" (that is logically equivalent to the following sentence: "If facts and documents and an additional document that is missing, then a trial verdict"). For instance: "Five branded sheep were seen in the flock of Kinnaya. Zēriya testifies against Kīnaya, proving that Kinnaya stole three of the sheep. The assembly decrees that Kinnaya must repay those sheep thirtyfold. Kinnaya claims that the remaining two sheep were given to him by a shepherd. Kinnaya must present the shepherd to the administrators of the Eanna. If he does not present the shepherd, then Kinnaya must repay the Eanna thirtyfold for those two sheep, as well [29 October, 547 B.C.]" [2, p. 52].

After the detailed analysis of Babylonian business correspondence and trial records we can assume that the Babylonians used inference rules which are analogous to the Talmudic middot (Hebrew: "logical rules"), first of all to the Hillel rules. Thus, we can claim that symbolic logic appears first not in Greece, but in Mesopotamia and this tradition was grounded in the Sumerian/Akkadian jurisprudence and the Talmud preserves this tradition for us until today. The only known codification of the Greeks is the Law Code of Gortyn (Crete, the $5^{\text {th }}$ century B.C.). It was made within the Babylonian legal tradition. In this way the Greek logic was established within a Babylonian legal hermeneutics. Hence, a Sumerian-Akkadian symbolic logic was first over the world.

\section{Particulars and Generals in Legal Reasoning}

There are the following two logical notions which are fundamental for our logical reasoning in the everyday life: 'particular' (representing a case or species) and 'general' (representing a genus). In the meanwhile, a particular $A$ is regarded as a case of an appropriate general $B$ so that this general $B$ is implied by this particular $A$ just logically. For instance, the following conditional statement is ever true: "If it is a silver fir $(A)$, then it is a tree $(B)$ " ("Each silver fir $(A)$ is a tree $(B)$ "), where "silver tree" is a particular and "tree" is a general. Hence, if the implication $A \Rightarrow B$ is semantically true, it means that $A$ is a particular case from $B$ and $B$ is a general characteristics for $A$. 
The idea how to differ particulars and generals and how to use this difference for constructing true implications is not so easy. There is only one culture that has born this idea to life. That was the Sumerian-Akkadian culture. Let us exemplify the fact that it was not so simple to think up this logical foundation for any implication. In the Chinese language, we can correctly utter: "A horse is a horse, two horse is a horse" (ȳ mă mă e, èr mă mă e). Hence, we do not differ there (i) "a horse" as a real horse that can serve as a particular instance (subject) for our reasoning and (ii) "a horse" as a general notion that can be a general characteristics (predicate) for real items. In fact, Mohists syllogisms are rather sophisms which were based on mixing particulars and generals in this exemplified way.

In the Sumerian and Akkadian codes of laws, for the first time there were introduced some general notions as generalizations of particulars. The word to denote a generalization is mimma or mimma šumšu (Akkadian: "whatever"), e.g.: mimma mala iddinu ìtelli (Laws of Hammurabi §113, $\S 116$, see [5]) "Whatever he originally gave as the loan." Implicitly, it means that suitable Hammurabi laws $\S 113$ and $\S 116$ concerning all the items given as the loan cover all the cases: "If there is whatever he originally gave as the loan, then rules $\S 113$ and $\S 116$ should take place." Let us assume that somebody gave an ox as the loan. Then we can apply the following composite implication: "If he gave an ox as the loan $(A)$, then it is the case of whatever he originally gave as the loan $(B)$. From this it follows that rules $\$ 113$ and $\S 116$ of the Law Code of Hammurabi should be applied for giving this ox as the loan $(C)$." Formally: $((A \Rightarrow B) \&(B \Rightarrow C)) \Rightarrow(A \Rightarrow C)$. Hence, this mimma ("whatever") assumes a logically correct construction of conditional propositions (implications) with a logical rule of transitivity of implication. All the same is as it holds in the modern symbolic logic.

The expressions "a man who..." (awīlum ša ...) and "a woman" (sinništum) from the Laws of Hammurabi are related to all human beings according to their gender. Both expressions are another form to denote a generalization. Each actor is examined as a particular case of awīlum or sinništum covered by appropriate rules of the Laws of Hammurabi. Also, there are many other expressions in Akkadian denoting "whoever" such as mannummê and attamannu.

Thus, the Sumerian-Akkadian codes of laws allow us to appeal to general notions assuming that they cover all the particular instances. As a result, in these codes, for the first time the implication as a kind of logical proposition with a correct semantics was introduced. Each article of the code, i.e. each rule, is formulated in the form of implication: "If/when (Akkadian: šumma) this or that occurs, this or that must be done as a trial judgment." The Semitic legal tradition (including the Talmud) is a continuation of the Sumerian and Akkadian law formulations. So, in the Bible we can find out the following three ways of law formulations which are typical for non-Jewish Aramaic legal texts, also:

(1) 'Casuistic': "If/when (non-Jewish Aramaic: $h n$ or ' $m$ ) this or that occurs, this or that action must be undertaken or this or that punishment must be inflicted." This $h n$ or ' $m$ is a derivation from the Akkadian šumma. An example from the Bible is as follows:

If [ $w$ 'im] he has not been redeemed in any of those ways, he and his children with him shall go free in the jubilee year (Leviticus 26:54).

(2) 'Apodictic': "Thou shall not... (non-Jewish Aramaic: prohibitions in the second person singular of the imperfect, sometimes by using the negative particle $l$ ')." A Biblical example:

Do not $\left[l^{\prime} o\right]$ deal basely with your countrymen. Do not [l'o] profit by the blood of your fellow: I am the Lord (Leviticus 19:16).

(3) 'Relative': "The man who... (non-Jewish Aramaic: '`̌s $z \bar{l}$ or gabar $z \bar{l}$ or 'enāš $z \bar{l})$ " or "Whoever ... (non-Jewish Aramaic: $z \bar{l}$ or $m n$ )." This $z \bar{l}$ or $m n$ is a derivation from awìlum and sinništum. Some examples from the Bible: 
And the Lord said to Moses: Whoever $[m \bar{l}]$ sinned against Me, him shall I erase from My book (Exodus 32:33).

If $[k \bar{l}]$ a man [ $\bar{\imath} \bar{l} \bar{s}]$ has a wayward and defiant son, who does not heed his father or mother and does not obey them even after they discipline him (Deuteronomy 21:18)

And whoever [we kol hanefeš ] does any work throughout that day, I will cause that person to perish from among his people (Leviticus 23:30).

It is worth noting that in the Torah, the word kol (Hebrew: "all") is often used for expressing the notions "whoever" and "whatever." It is a loanword derived from the following Akkadian words: kala, kali, kaluma ("everything," "everyone," "everybody").

Hence, the Sumerian/Akkadian legal style was integrated in the broader context of Near Eastern juridical terminology.

The only Greek law code preserved until now is the Law Code of Gortyn (see its text in [8]) written in the Dorian dialect and dated to the first half of the $5^{\text {th }}$ century B.C. It was a codification of the civil law of the ancient Greek city-state of Gortyn located in southern Crete. It is a type of stone inscription on the wall of a public civic building in the agora of Gortyn. Its script style is called boustrophedron, in which alternate lines must be read in opposite directions rather than from left to right, or right to left. This code contains the articles formulated in the form of implications $\alpha i$ $\delta \varepsilon ́ . .$. (the Dorian dialect of Old-Greek: "and if...") in the way of Sumerian/Akkadian legal tradition.

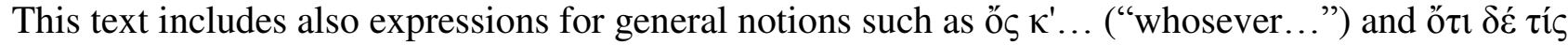
$\kappa ' . .$. (“and whatever anyone..."), etc.

In the Stoic propositional logic established by Chrysippus (c. 279 - c. 206 B.C.), the general notions are expressed in the way of legal tradition by the terms "whatever" and "whoever" as well as it was done in the Laws of Hammurabi first, and later in the Greek law codes like the Law Code of Gortyn. For instance, the well-known proposition "Man is a rational, mortal animal" (őv $\theta \rho \omega \pi o ́ s$

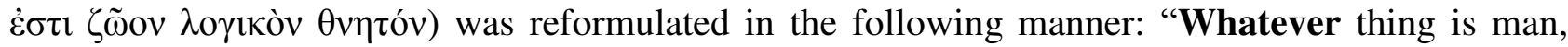

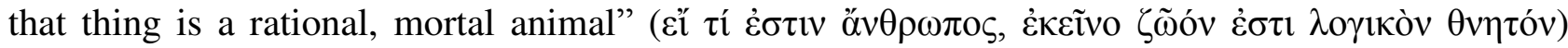
(Sextus Empiricus, Against the Ethicists 9). Another example of Stoic universal affirmative propositions: "Whosoever are men, they are either Greeks or barbarians" ( $\tau \tilde{\omega} \nu \dot{\alpha} v \theta \rho \omega ́ \pi \omega \nu$ oi $\mu \varepsilon ́ v$

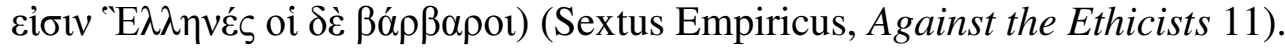

The main difference of the Stoic formulation of universal affirmative propositions from the Aristotelian one is that the Stoic formula is interpreted as an implication immediately: "Whatever is $A$, it is $B$ " is understood as "If $A$, then $B$. " All the same as it took place in the Sumerian/Akkadian legal culture.

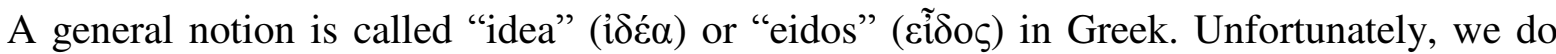
not know how these terms were used in the Greek legal hermeneutics, because no Greek legal commentaries or trial records were preserved. Nevertheless, we know very well how the Sumerian/Akkadian difference between generals and particulars is applied in the Talmudic legal commentaries. In the Talmud, there are the following two significant logical terms: 'general' (klal) and 'particular' (prat), traditionally involved into commentaries.

Let us consider a conventional Judaic legal commentary on the following Biblical verse:

Thou shalt not covet thy neighbour's house, thou shalt not covet thy neighbour's wife, nor his manservant, nor his maidservant, nor his ox, nor his ass, nor any thing that is thy neighbour's (Exodus 20:17).

Rabbi Yišm'a'el pays our attention on that "Thou shalt not covet thy neighbour's house" is a general concept $(\mathrm{klal})$ that is followed by several particular instances (prațim): "Thy neighbour's 
wife, nor his manservant, nor his maidservant, nor his ox, nor his ass." And at the end of the verse we again face a general ( $k l a l)$ : "Nor any thing that is thy neighbour's." According to Rabbi Yišm'a'el, this sequence started from a general and gone to a particular and then again to a general is a case for applying the Judaic inference rule that is called 'general-particular-general' (klal u-prat $u-k l a l)$ :

"You shall not covet your neighbor's house" - general [כלל]. "And his man-servant, and his maid-servant, and his ox, and his ass" - particular [פרלט]. General-particular [כלל ופרט] (The rule is:) There exists in the general only what exists in the particular. "And all that belongs to your neighbor" - reversion to the general. (This leaves us with) general-particular-general (The rule is:) You deduce only what is in accordance with the particular, viz.: Just as the particular is something which is acquired and bestowed, so, all that is acquired and bestowed (comes under "You shall not covet," [and not coveting another's learning]). But then, why not say: Just as the particular speaks of movable property, which does not serve as surety, so, all such property ([and not land] comes under "You shall not covet")? Since it is written (in this context) in the second Decalogue "his field," (we must revert to) "Just as the particular is something which is acquired, etc.") Or, just as the particular does not enter your domain except with the acquiescence of the owner, so all such things (are subsumed in "You shall not covet") to exclude one's coveting another's daughter for your son or his son for your daughter. I might think that (if one covets) in speech, (he is in transgression of "You shall not covet;" it is, therefore, written "You shall not covet the silver and gold upon them and take, etc." Just as there, he is not (in transgression of "You shall not covet") until he performs an act, so, here (Mekhilta d'Rabbi Yishmael 20:14:3, translated by Rabbi Shraga Silverstein).

Thus, for the first time, particulars and generals started to be distinguished logically in the Sumerian/Akkadian legal hermeneutics. The Sumerians and Akkadians founded a legal system for which trial decisions had to be reached by deducing them from the law code by applying the following two inference rules which are basic now for the modern symbolic logic, too: modus ponens and modus tollens. Recall that modus ponens is formulated as follows: if two sentences $A$ and $A \Rightarrow B$ are true, then the sentence $B$ is true, also. The rule of modus tollens: if the sentence $A \Rightarrow$ $B$ is true and the sentence $B$ is false, then the sentence $A$ is false, too. Each law code contains implications $A \Rightarrow B$ which are examined as true forever. Each court should have considered a factual case $C$ of indictment that was verified by testimonies or signed documents and then the court should have found out an appropriate general $A$ for this $C$. After that the court judgment can have deduced a verdict $B$ by modus ponens applied two times:

$$
A \Rightarrow B ; C \Rightarrow A ; C
$$

$B$.

The latter sentence is a verdict what should be done (which punishment $B$ should be chosen) according to the rule $A \Rightarrow B$ from the code of laws.

If the situation $C$ of indictment was not suitable for the legal rule $A \Rightarrow B$ from the code, modus tollens was applied one time:

$$
C \Rightarrow A ; A \Rightarrow B ; \neg A
$$

$\neg C$. 
Hence, the task of any court is to examine all the facts, such as testimonies or signed documents, for verifying the indictment $C$ or falsifying its general case $A$ within an appropriate law $A \Rightarrow B$. Therefore, 'making a decision by a court' was called dīna parāsu in Akkadian, where dīna means "law" and parāsu means "to separate," "to divide," or "to get a particular." In other words, the direct meaning of dina parāsu is to deduce something from a law or to make a particular case within a law. Thus, dīna parāsu became the first word denoting a deduction as such in human languages. 'Examining the facts' was called warkata parāsu in Akkadian. It is worth pointing out that 'giving a decision by an omen' was called dīna šakānu - "to establish a law." Omens in Akkadian were formulated by conditional propositions "If... then..." too and dīna šakānu meant to put forward a conditional law.

Let us return to the Talmudic difference between a particular (prat) and a general (klal). The logical term klal came from the Akkadian word kalu ("all" or "totality"), in Hebrew kol, while prat with the meaning parat ("to separate," "to divide," or "to get a particular") came from the Akkadian word parāsu. In Hebrew there is another term paras to denote the verb "to separate" and "to divide." It came from the Akkadian parāsu also. Nevertheless, for denoting a logical notion to be a particular or an individual case only parat is used. The meaning of dīna parāsu as a deductive trial judgment was shared in Judaism. So, there is the following well-known Judaic rule: "We do not make decisions as generals (haklalot)" (אין למדין מן הכללות), since "We make decisions only as particulars (haprațìm)" - we should follow dìna parāsu in all our judgments.

The ability to distinguish particulars from generals purely logically is not so easy. In Indian philosophy this ability appeared quite late (only after the Pāli Canon, i.e. after the $1^{\text {st }}$ century A.D.). For instance, in the Yamaka, belonging to the Abhidhammapitaka of the Pāli Canon, there are considered many possible pairs of different abstract entities $A$ and $B$ within the following four possible answers to the question 'Is $A B$ ? But is $B A$ ?': (i) 'All $A$ are $B$ ' and 'All $B$ are $A$ ' (it means, $A$ and $B$ are generals); (ii) 'All $A$ are $B$ ' and 'Not all $B$ are $A$ ' (i.e. 'Some $B$ are not $A$ ') (it means, $A$ is particular and $B$ is general); (iii) 'Not all $A$ are $B$ ' (i.e. 'Some $A$ are not $B$ ') and 'All $B$ are $A$ ' (it means, $A$ is general and $B$ is particular); (iv) 'Not all $A$ are $B$ ' (i.e. 'Some $A$ are not $B$ ') and 'Not all $B$ are $A$ ' (i.e. 'Some $B$ are not $A$ ') (it means, $A$ and $B$ are particulars). The answers allow us to affirm whether $A$ and $B$ are general or particular. Hence, on the one hand, in the Yamaka, the Indian author knows what is general, and what is particular, but, on the other hand, he does not know how to infer from the difference between particulars and generals. He does not use any inference rule. In the Pāli Canon, the only book, whose author knows how to infer from distinguishing particulars and generals correctly indeed, is the Milindapañha written in Hellenized Gandhāra.

The textual evidence illustrated above that the logical thinking appeared in India and China much, much later than in Babylonia is explained by different understandings of legality in these cultures. While in Babylonia there holds the Akkadian concept of law, dina (Hebrew: dinn), as a legal proceeding made by logical deductions, in India there was the Hindu concept of law, dharma (Pâli: dhamma), and in China - the Chinese concept of law, dào, quite close to the dharma. While dìna is formalizable logically, dharma as well as dào is not at all, by their primary definitions.

The Edict of Aśoka, the Indian emperor of the Maurya Dynasty who ruled almost the whole Indian subcontinent from c. 268 to 232 B.C., became the first law document as such, issued in India. It is worth noting that it was written down on the stone wall or stele, too - in the Babylonian (Sumerian/Akkadian) style that was obviously borrowed. This text was written in a Prakrit close to Pāli. But several translations of the Edict into some other languages were published simultaneously with the main text. The Greek and Aramaic versions of this Edict excavated in Kandahar are unique, because they can be regarded as an outer cultural commentary to the concept of dhamma of Aśoka, proposed by a Greek scholar/philosopher and by an Aramean legist/“Talmudist." Let us consider first the Greek commentary:

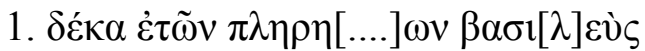

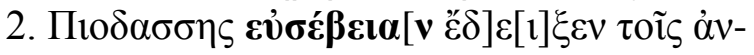




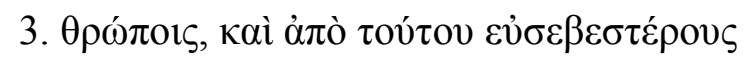

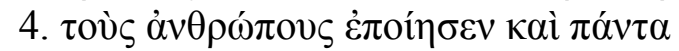

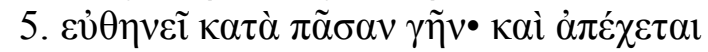

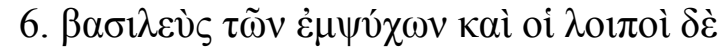

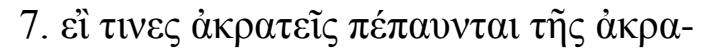

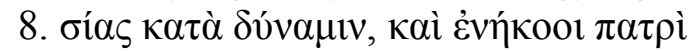

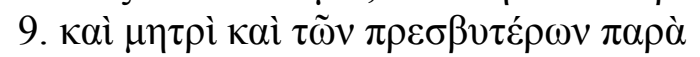

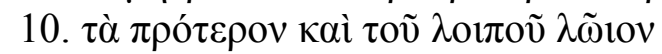

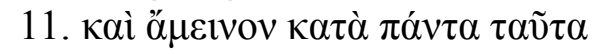

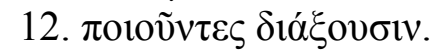

Ten years being completed king Piyadassi [A.Sch.—Aśoka] showed piety (i.e. Dhamma) [A.Sch. - $\varepsilon \dot{\sigma} \sigma \varepsilon \dot{\beta} \varepsilon 1 \alpha$ ] to men. And from that time [onwards] he made men more pious. And all things prosper throughout the whole world. And the king refrains from [eating] living beings, and indeed other men and whosoever [were] the king's huntsmen and fishermen have ceased from hunting, and those who were without control [over themselves] have ceased as far as possible from their lack of [self-] control, and [have become] obedient to father and mother and to elders, such as was not the case before. And in future, doing all these things, they will live more agreeably and better than before [7, p. $260-261]$.

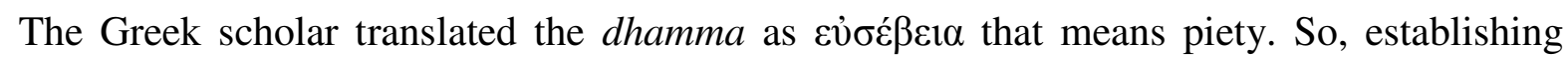
dhamma in the Empire by Aśoka meant, for the Greeks, establishing a priority of religious customs in the everyday life.

The Aramean jurist was more rigorous in his commentary than the Greek author:

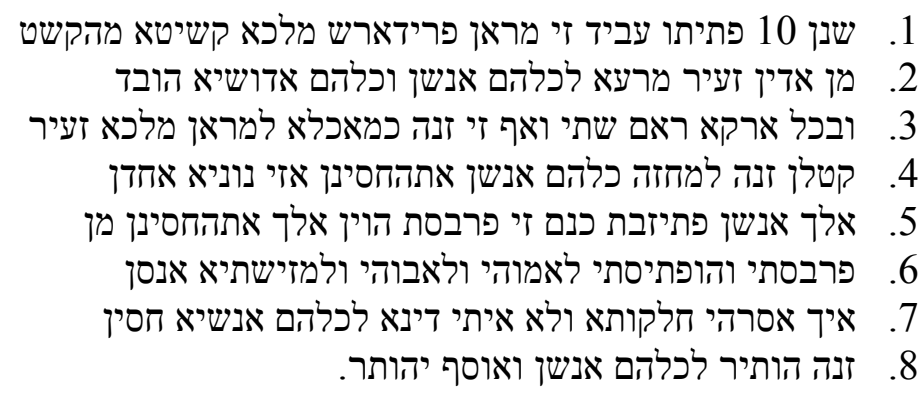

Ten years having passed, our Lord the king Piyadassi [A.Sch.—Aśoka], decided to instruct men in Dhamma. Since then, evil among men has diminished in the world. Among those who have suffered it has disappeared, and there is joy and peace in the whole world. And even in another matter, that which concerns eating, our Lord the king kills very few animal.

Seeing this the rest of the people have also ceased from killing animals. Even those who catch fish, their activity has been prohibited. Similarly those that were without restraint have now learnt restraint. Obedience to mother and father, and elders, and conformity with the obligations implied in this, is now in practice. There are no more trials for men of piety. Thus the practise of Dhamma is of value to all men, and it will continue to be so [7, p. $260-261]$.

This translation of the Aramaic text is not adequate absolutely. The much more correct translation is as follows:

1. For ten years penitence was made by Our Lord, Prīyad'arš [פרידארש], the king, showing [מהקשט]] a straight way [קשיטא]]. 
2. Since that time evil decreased for all men $[k l h m$ 'nšn $]$ and he destroyed all the confrontation.

3. And a foundation [ $\check{s} t \bar{l}]$ arose on the whole earth [wbkl 'rq']. And besides, it is in respect to the food: for Our Lord, the King, little

4. is slaughtered. Seeing this all men have ceased [to do it]. And those men who $[z \bar{l}]$ were catching living beings [zwny'],

5. have been forbidden [to do it]. Thus, who were bound, those ceased to

6. be bound. And good obedience [is observed] to his mother and to his father and to the elder men

7. as destiny imposed upon him. And the law $\left[\operatorname{din}^{\prime} a\right]$ does not exist in respect to anyone who is strong.

8. This benefited all men and will benefit all them.

Hence, the Aramean "Talmudist" translated the dhamma of Aśoka in the following two manners: (i) the dhamma is a simple/straight way proposed by the King Prīyad'arš ( פרידארש מלכא קשיטא מהקשט (ii); this way is not a law [din'a]; as a result, if we follow the dhamma, we do not need any legal proceeding [the same term dīn'a] at all (ולא איתי דינא לכלהם אנשיא חסין). It means that the dhamma is before any law and cannot be formalizable as the Akkadian dina (i.e. as the Aramaic din'a). In the Talmud, there is a concept of 'fundamental ethics' called 'road of the earth' (derek 'erez, דרך ארץ) which denotes the ethics before the Judaic legality that is called din Torah (Hebrew: "the law of the Torah"). Respectively, this Hebrew concept of the "road of the earth' is close to the dhamma as it was understood by the author of the Aramaic version of the Edict.

In the Hebrew Qabbalah, the Aramaic word din'a denoting a law has rather negative connotations linking legality just to prohibitions, too. The matter is that since the $1^{\text {st }}$ century A.D. the post-Akkadian approach to legality with an emancipation from the strong $d \bar{i} n$ ' $a$ has taken place in the Aramaic world including Judea of that time; according to this approach, ethics started to be considered more important than any law. This post-Akkadian approach was very well expressed in Christianity, first Syriac/Aramaic.

Thus, dhamma cannot be formalized by series of implications. So, it is out of any logic in principle. This evidence was well seen by the author of the Aramaic version of the Edict of Aśoka, also. Therefore, we cannot find out any implication in this Edict. This text is out of logic.

To sum up, we know that the Achaemenid Dynasty ruled the northern part of India for about 200 years before the Greco-Macedonian foray into India in ca. 327 B.C. And this dynasty was based on the Akkadian legal tradition with the Aramaic language got official over the whole Achaemenid Empire. Therefore, the Aramaic commentary to the Edict, mentioned above, is so significant. This commentary shows that Aśoka performed the following social reforms: (i) he approved a priority of religious customs in decision-making (he established a kind of theocracy); (ii) he rejected the Achaemenid $d \bar{i}$ ' ' $a$ and validated emancipation from the law.

Nevertheless, the Akkadian-type legality came back later to India due to sharing the Hellenistic legal culture that was so close to the Semitic one. Since Alexander the Great's invasion of the Indus Valley, there have been founded several Hellenistic states in India: Bactria or the IndoGreek Kingdom (from the $3^{\text {rd }}$ century B.C. to the $1^{\text {st }}$ century B.C.), the Indo-Scythian Kingdom (from the $1^{\text {st }}$ century B.C. to the $1^{\text {st }}$ century A.D.), the Kushan Empire (from the $1^{\text {st }}$ century to the $4^{\text {th }}$ century A.D.). In these states Greek was used as an official language; first of all, it was used for edicts, trading and receiving taxes. At the same time, Gāndhārī played the role of sacral language for liturgy and philosophy.

The change of the official language in the Kushan Empire from the Greek language to the Bactrian one is fixed in the Rabatak inscription of the Edict of Kanișka, the king of the Kushan Empire. This Edict was issued in 127 A.D. and it was found in 1993 at the site of Rabatak, near Surkh Kotal in Afghanistan. So, Kanișka was the first who replaced the use of Greek by the "Aryan" language after the 400-years history of the Greek and Greco-Scythian communities in the 
North-West of India. In fact, this "Aryan" language was Bactrian - one of the Old-Eastern-Iranian dialects with many loanwords from Greek.

The text of the Edict was written in the Greco-Bactrian script:

1

5

10

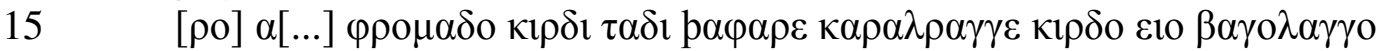

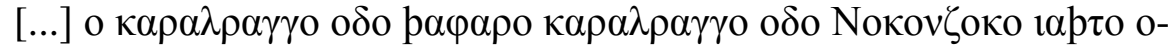

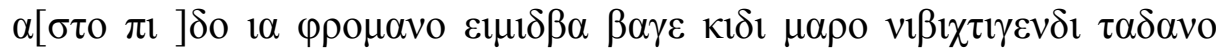
$\alpha \beta o$ paov-

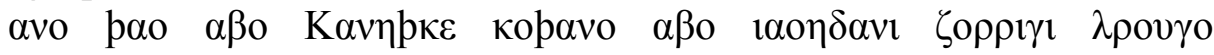
$\alpha \gamma \gamma \alpha[\mathrm{o}] \alpha \gamma \gamma \mathrm{o}$ o $\alpha v \mathrm{v} v \delta-$

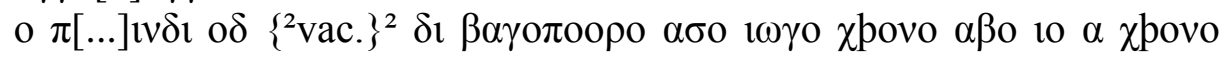

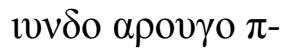

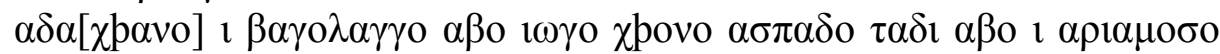

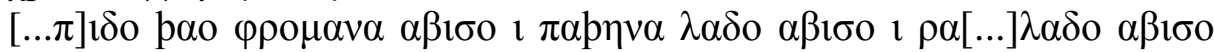

$[\ldots]$

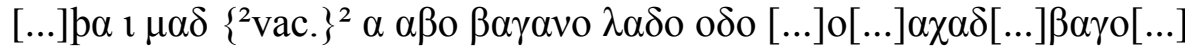

$[-----]$

(the reconstruction of the Edict is cited from [6, p. $77-81]$ ).

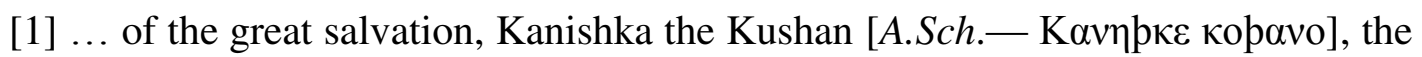
righteous, the just, the autocrat, the god [2] worthy of worship, who has obtained the kingship from Nana and from all the gods, who has inaugurated the year one [3] as the gods pleased. And he *issued a Greek *edict (and) then he put it into Aryan. 
[4] In the year one it has been proclaimed unto India, unto the *whole of the realm of the *kshatriyas, that (as for) [5] them - both the (city of) ... and the (city of) Saketa, and the (city of) Kausambi, and the (city of) Pataliputra, as far as the (city of) Sri-Campa [6] - whatever rulers and other *important persons (they might have) he had submitted to (his) will, and he had submitted all [7] India to (his) will. Then King Kanishka gave orders to Shafar the karalrang [8] *at this ... to make the sanctuary which is called B ... ab, in the *plain of Ka ..., for these [9] gods, (of) whom the ...* * glorious Umma leads the *service here, (namely:) the *lady Nana and the [10] lady Umma, Aurmuzd, the gracious one, Sroshard, Narasa, (and) Mihr. [interlinear text: ... and he is called Maaseno, and he is called Bizago] And he likewise [11] gave orders to make images of these gods who are written above, and [12] he gave orders to make (them) for these kings: for King Kujula Kadphises (his) great [13] grandfather, and for King Vima Taktu, (his) grandfather, and for King Vima Kadphises [14] (his) father, and *also for himself, King Kanishka. Then, as the king of kings, the devaputra [15] ... had given orders to do, Shafar the karalrang made this sanctuary. [16] [Then ...] the karalrang, and Shafar the karalrang, and Nukunzuk [led] the worship [17] [according to] the (king's) command. (As for) *these gods who are written here - may they [keep] the [18] king of kings, Kanishka the Kushan, for ever healthy, *secure, (and) victorious. [19] And [when] the devaputra, the *ruler of all India from the year one to the year *one *thousand, [20] had *founded the sanctuary in the year one, then *also to the ... year ... [21] according to the king's command ... (and) it was given also to the ..., (and) it was given also to the ..., (and) also to [22] ... the king gave an *endowment to the gods, and ... [6, p. $77-81]$.

1-3 The year one of Kanișka, the great deliverer, the righteous, the just, the autocrat, the god, worthy of worship, who has obtained the kingship from Nana and from all the gods, who has laid down (i.e. established) the year one as the gods pleased.

3-4 And it was he who laid out (i.e. discontinued the use of) the Ionian [A.Sch.Greek] speech and then placed the Arya (or Aryan) speech (i.e. replaced the use of Greek by the Aryan or Bactrian language).

4-6 In the year one, it has been proclaimed unto India, unto the whole realm of the governing class including Koonadeano (Kaundinya) and the city of Ozeno (Ozene) and the city of Zageda (Saketa) and the city of Kozambo (Kausambi) and the city of Palabotro (Pataliputra) and so long unto (i.e. as far as) the city of Ziri-tambo (ŚriChampa).

6-7 Whichever rulers and the great householders there might have been, they submitted to the will of the king and all India submitted to the will of the king.

7-9 The king Kanișka commanded Shapara (Shaphar), the master of the city, to make the Nana Sanctuary, which is called (i.e. known for having the availability of) external water (or water on the exterior or surface of the ground), in the plain of Kaeypa, for these deities - of whom are Ziri (Śri) Pharo (Farrah) and Omma.

9-9A To lead are the Lady Nana and the Lady Omma, Ahura Mazda, Mazdooana, Srosharda, who is called ... and Komaro (Kumara) and called Maaseno (Mahasena) and called Bizago (Visakha), Narasao and Miro (Mihara).

10-11 And he gave same (or likewise) order to make images of these deities who have been written above.

11-14 And he ordered to make images and likenesses of these kings: for king

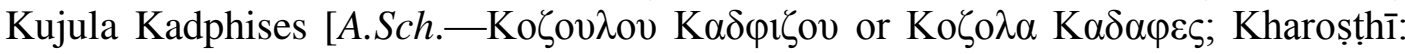
Kujula Kasasa; Ancient Chinese: 丘就卻, Qiujiuque; reigned 30-80 A.D.], for the great grandfather, and for this grandfather Saddashkana (Sadașkaṇa), the Soma 


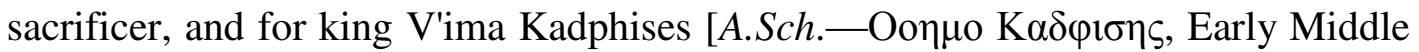
Chinese: 阎膏珍, Jiam-kaw-trin; reigned 90-100 A.D.], for the father, and for himself (?), king Kanișka.

14-15 Then, as the king of kings, the son of god, had commanded to do, Shaphara, the master of the city, made this sanctuary.

16-17 Then, the master of the city, Shapara, and Nokonzoka led worship according to the royal command.

17-20 These gods who are written here, then may ensure for the king of kings, Kanișka, the Kushana, for remaining for eternal time healthy, secure and victorious ... and further ensure for the son of god also having authority over the whole of India from the year one to the year thousand and thousand.

20 Until the sanctuary was founded in the year one, to (i.e. till) then the Great Arya year had been the fashion.

21 ... According to the royal command, Abimo, who is dear to the emperor, gave capital to Pophisho.

22 ... The great king gave (i.e. offered worship) to the deities

(this translation is taken from [4]).

No law codes from the Hellenistic states in India, unfortunately, were preserved. However, there are many indirect evidences that they were of the Greek-Semitic style. So, there are excavated some early business and taxation documents in Greek and many later real estate, trading, and taxation documents written in Bactrian in the Greco-Bactrian script and prepared in the Hellenistic way, e.g. they were made from leather, which is absolutely untypical for India. These documents are evidences that in the North-West of India, most probably, a Hellenistic codification of the civil law was implemented.

The Hellenistic legal context is a good explanation of the fact why the nyāya school of logic as well as the Buddhist (yogāeāra) logic were simultaneously founded in the $2^{\text {nd }}$ century A.D. in Gandhāra, the center of the Kushan Empire, namely in the region, where the Greek language was official for more than three centuries.

The Akkadian-Aramaic legality with a good tradition of logical deductions for legal hermeneutics was continued by the Greek legal culture and, then, this Hellenistic culture flourished also in Gandhāra. The tradition of that legality was so influential among the neighbor regions. For instance, the Kushan way of legality was implemented also in the Kingdom of Khotan, the Scythian Buddhist kingdom existed from the $3^{\text {rd }}$ century to the $4^{\text {th }}$ century A.D. and located on the branch of the Silk Road in the modern Xinjiang, China. In this kingdom Gāndhārī, the sacral language of the Buddhists of Gandhāra, was official. At the Tarim Basin site of Niya there were excavated many documents written in Gāndhārī in the Kharoșthī script, where a law code is mentioned:

His majesty, etc. [...] Sugita informs us that he paid a price for a woman Sugisae. The price was forty-one rolls of silk. When this sealed wedge-tablet reaches you, forthwith you must carefully inquire in person, whether she was really bought. A decision must be made according to law. Against the law officials must not take possession of that woman. If you are not clear about it there, there will be a decision when they appear in our presence at the royal court [1].

In turn, the legality of the Kingdom of Khotan influenced on the Chinese legal tradition trough the mahāyāna Buddhism. For example, in Buddhism there are the following 'ten evil acts' ( 十悪): (i) the three physical evil acts: killing, stealing, and sexual misconduct; (ii) the four verbal evils: lying, slander, coarse speech, and empty chatter; (iii) and the three mental evils: greed, anger, and foolishness. This Buddhist reflexion on evils influenced on defining the 'ten abominations' (十 恶), fundamental for the Chinese traditional legality, first formulated in the legal documents of the 
Northern Qi ruled northern China from 550 to 577. They are as follows: (i) plotting a rebellion (謀 反) against the ruler or parent; (ii) plotting a great sedition (謀大逆), first of all, damaging the royal temples or palaces; (iii) plotting a treason (謀叛); (iv) a contumacy (惡逆) including harming or murdering the parents and grandparents or husband's elder relatives; (v) a depravity (不道) murdering three or more innocent people in one family; (vi) a great irreverence (大不敬) towards some sacral things and a disrespect to the Emperor or his family; (vii) a lack of filial piety (不孝), including maltreating the parents or grandparents; (viii) a discord (不睦) - harming the husband or elder relatives; (ix) an unrighteousness (不義) - a petty treason including murdering local government officials; (x) an incest (內亂).

Let us draw our first conclusions:

1. For the first time, the logical notions 'particular' ('species') and 'general' ('genus') and appropriate logical inference rules including modus ponens and modus tollens were proposed for legal proceedings in the Sumerian/Akkadian culture.

2. The Akkadian concept of dīna (Aramaic dīn'a and Hebrew dīn) implicitly assumes a formalization of law and a logical technique with deducing verdicts from the law code and verified facts.

3. The Greek tradition of logic is much younger than the Babylonian one and it appeared due to adopting the Semitic legal tradition with a deductive logic for the Greek legal proceedings.

4. The logical techniques of the Talmud are quite authentic to the original logic established by the Sumerians and Akkadians first.

5. The nyāya school of logic as well as the Buddhist (yogācāra) logic was founded in the $2^{\text {nd }}$ century A.D. in Gandhāra because of adopting a Hellenistic legal tradition in this country.

\section{On the Semitic Roots in the Law Code of Gortyn}

The text of the Law Code of Gortyn is an important evidence that the civil laws were interpreted by the Greeks in the way of the Akkadian concept of dina (Aramaic din' 'a or Hebrew dinn): (i) from this code, a legal proceeding is contextually reconstructed as almost the same as the Semitic legal proceedings; (ii) in this code, we see a formalization of laws that is very similar by their articles to the Semitic codifications first proposed by the Akkadians.

Let us consider first some similarities to Semitic legal proceedings. For instance, there is a requirement in the Law Code of Gortyn to support the own position at a court by a testimony from a minimum of two witnesses: "In the presence of two free adult witnesses" [8, p. 39]. The same number occurs in the Neo-Babylonian trial records (see [2]). Sometime there can be an additional witness, but in the Semitic legal tradition, it was accepted that two witnesses are a sufficient amount of testimonial evidence. The Judaic law requires the same amount of two, as it is seen in the Judaic commentaries to the following Biblical verse:

One witness shall not rise up against a man for any iniquity, or for any sin, in any sin that he sinneth: at the mouth of two witnesses, or at the mouth of three witnesses, shall the matter be established (Deuteronomy 19:15).

The most principal thing in similarities to the Semitic juristic culture is that a judge in the Law Code of Gortyn is assumed to be an expert in deducing verdicts from the implications of the code by logical inference rules (first of all, by modus ponens and modus tollens). That is the same as it was supposed in the Semitic legal proceedings.

Also, there are many direct similarities to Semitic law formulations. For example, among Semitic tribes there was a tradition of levirate marriage, according to that if a man dies and he has no son or daughter, then the wife of the dead man shall not get married to a stranger, but her husband's brother shall take her for himself as a wife: 
If brethren dwell together, and one of them die, and have no child, the wife of the dead shall not marry without unto a stranger: her husband's brother shall go in unto her, and take her to him to wife, and perform the duty of a husband's brother unto her (Deuteronomy 25:5).

In the Law Code of Gortyn the levirate marriage is defined as follows:

The heiress is to be married to the brother of her father [A.Sch.-husband?], the oldest of those living. And, if there be more heiresses and brothers of the father, they are to be married to the next oldest.

And if there should not be kinsmen of the heiress as is defined, she may hold all of the property and be married to whomsoever she may wish from the tribe. And if no one from the tribe should wish to marry her, the relatives of the heiress are to proclaim throughout the tribe: "Does no one wish to marry her?" And if anyone should marry her, (it should be) within thirty days from the time they made the proclamation; but if not, she is to be married to another, whomsoever she can. And if a woman becomes an heiress after her father or brother has given her (in marriage), if she should not wish to remain married to the one to whom they gave her, although he be willing, if she has borne children, she may be married to another of the tribe, dividing the property as is prescribed; but if there should be no children, she is to be married to the groom-elect, if there be one, and take all the property; and if there is not, as is prescribed [8, p. $45-46]$.

The Law Code of Hammurabi (see Figure 1) is one of the oldest well-preserved Babylonian law codes. It is dated to ca. 1728 - 1686 B.C. Thus, archeologically, it is regarded as one of the first well-detailed samples for all known Semitic legal traditions. The Law Code of Gortyn is much younger. So, it is dated just to the $5^{\text {th }}$ century B.C. Nevertheless, it is readily shown that a majority of the laws of Gortyn are similar to the laws of Hammurabi. It means that the Gortyn Greek laws have, obviously, Semitic roots.

For example, in the Law Code of Hammurabi the status, whether somebody is a slave, is a documented fact that can be ever proved by a court:

\$282 If a slave should declare to his master, "You are not my master," he (the master) shall bring charge and proof against him that he is indeed his slave, and his master shall out off his ear [5, p. 132].

A fugitive slave can be seized, but only to be led him or her back to his or her owner immediately:

\$17 If a man seizes a fugitive slave or slave woman in the open country and leads him back to his owner, the slave owner shall give him shekels of silver.

\$18 If that slave should refuse to identify his owner, he shall lead him off to the palace, his circumstances shall be investigated, and they shall return him to his owner [5, p. $84-85]$.

It is prohibited to hold a fugitive slave in captivity:

\$19 If he should detain that slave in his own house and afterward the slave is discovered in his possession, that man shall be killed.

\$20 If the slave should escape the custody of the one who seized him, that man shall swear an oath by the god to the owner of the slave, and he shall be released [5, p. $84-85]$. 


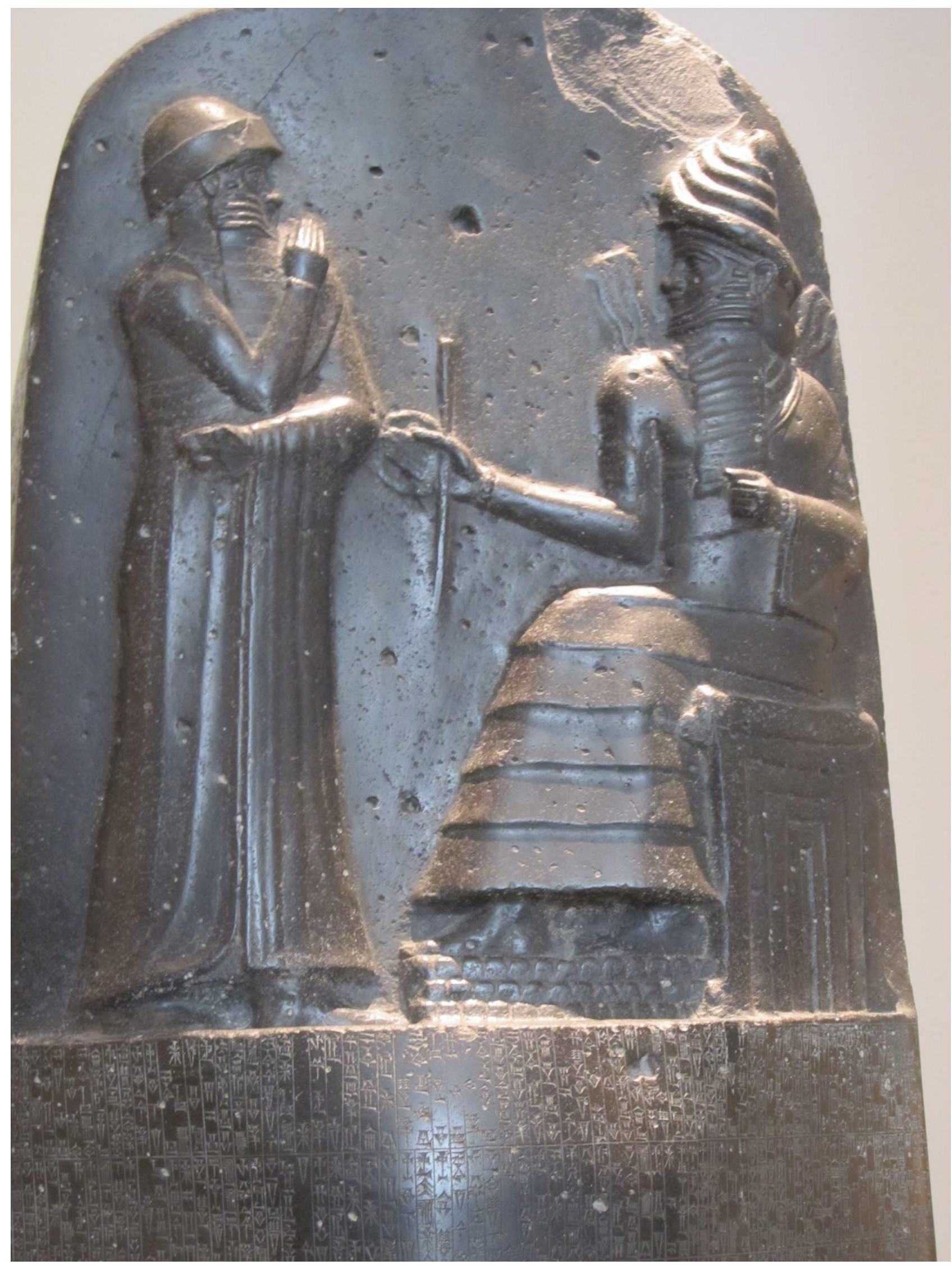

Figure 1. The stele of the Law Code of Hammurabi, Louvre Museum; by courtesy of Vladimir Sazonov. 
In the Law Code of Gortyn we see a prohibition to hold a fugitive slave in captivity, also, and it is well expressed, too, that the decision, whether somebody is a slave indeed, belong only to the court:

Whosoever may be likely to contend about a free man or a slave is not to seize him before trial. But if he make seizure, let (the judge) condemn him to (a fine of) ten staters for a free man, five for a slave of whomsoever he does seize and let him give judgment that he release him within three days; but if he do not release him, let (the judge) condemn him to (a fine of) a stater for a free man and a drachma for a slave, for each day until he do release him; and the judge is to decide on oath as to the time; but if he should deny the seizure, unless a witness should testify, the judge is to decide on oath. And if one party contend that he is a free man, the other party that he is a slave, whichever persons testify that he is a free man are to prevail. And if they contend about a slave, each declaring that he is his, the judge is to give judgment according to the witness if a witness testify, but he is to decide on oath if they testify either for both or for neither. After the one in possession has been defeated, he is to release the free man within five days and give bade the slave in hand; but if he should not release or give bade, let (the judge) give judgment that the (successful party) be entitled, in the case of the free man to fifty staters and a stater for each day until he releases him, in the case of the slave ten staters and a drachma for each day until he gives him bade in hand; but at a year's end after the judge has pronounced judgment, the three-fold fines are to be exacted, or less, but not more [8, p. 39].

According to the Law Code of Hammurabi, if somebody forcibly seizes and rapes a virgin, then, first, the fornicator shall give "triple" the silver as the value of the maiden to her father and, second, her fornicator shall marry her, if her father agrees, and shall have no right to divorce her:

\$A 55 If a man forcibly seizes and rapes a maiden who is residing in her father's house, [...] who is not betrothed(?), whose [womb(?)] is not opened, who is not married, and against whose father's house there is no outstanding claim - whether within the city or in the countryside, or at night whether in the main thoroughfare, or in a granary, or during the city festival $-<\ldots>$ If he (the fornicator) has no wife, the fornicator shall give "triple" the silver as the value of the maiden to her father; her fornicator shall marry her; he shall not reject(?) her. If the father does not desire it so, he shall receive "triple" silver for the maiden, and he shall give his daughter in marriage to whomever he chooses [5, p. $174-175]$.

There is almost the same rule in the Torah:

If a man comes upon a virgin who is not engaged and he seizes her and lies with her, and they are discovered, the man who lay with her shall pay the girl's father fifty [shekels of] silver, and she shall be his wife. Because he has violated her, he can never have the right to divorce her (Deuteronomy 22:28-29).

In the Torah, almost all the sexual contacts beyond the marriage incur the death penalty:

If a man is found lying with another man's wife, both of them - the man and the woman with whom he lay - shall die. Thus you will sweep away evil from Israel. In the case of a virgin who is engaged to a man - if a man comes upon her in town and lies with her, you shall take the two of them out to the gate of that town and stone them to death: the girl because she did not cry for help in the town, and the man 
because he violated another man's wife. Thus you will sweep away evil from your midst. But if the man comes upon the engaged girl in the open country, and the man lies with her by force, only the man who lay with her shall die, but you shall do nothing to the girl. The girl did not incur the death penalty, for this case is like that of a man attacking another and murdering him (Deuteronomy 22:22-26).

The same highest penalty is supposed in the Law Code of Hammurabi for different sexual misconducts:

\$129 If a man's wife should be seized lying with another male, they shall bind them and throw them into the water; if the wife's master allows his wife to live, then the king shall allow his subject (i.e., the other male) to live.

\$130 If a man pins down another man's virgin wife who is still residing in her father's house, and they seize him lying with her, that man shall be killed; that woman shall be released.

\$131 If her husband accuses his own wife (of adultery), although she has not been seized lying with another male, she shall swear (to her innocence by) an oath by the god, and return to her house.

\$132 If a man's wife should have a finger pointed against her in accusation involving another male, although she has not been seized lying with another male, she shall submit to the divine River Ordeal for her husband.

\$133a If a man should be captured and there are sufficient provisions in his house, his wife [..., she will not] enter [another's house].

\$133b If that woman does not keep herself chaste but enters another's house, they shall charge and convict that woman and cast her into the water.

\$134 If a man should be captured and there are not sufficient provisions in his house, his wife may enter another's house; that woman will not be subject to any penalty.

\$135 If a man should be captured and there are not sufficient provisions in his house, before his return his wife enters another's house and bears children, and afterwards her husband returns and gets back to his city, that woman shall return to her first husband; the children shall inherit from their father [5, p. $105-106]$.

The corresponding articles of the Law Code of Gortyn are much more liberal, which can be explained by that they are quite later than the Torah. So, according to this code, the rape and sexual misconducts are punishable only with an appropriate fine:

If a person commits rape on the free man or the free woman, he shall pay one hundred staters; and if on account of an apetairos, ten; and if the slave on the free man or the free woman, he shall pay double; and if a free man on a male serf or a female serf, five drachmas; and if a male serf on a male serf or female serf, five staters. If a person should forcibly seduce a slave belonging to the home, he shall pay two staters; but if she has already been seduced, one obol by day, but if in the night, two obols; and the slave shall have preference in the oath. If someone attempt to have intercourse with a free woman who is under the guardianship of a relative, he shall pay ten staters if a witness should testify.

If someone be taken in adultery with a free woman in a father's, brother's or the husband's house, he shall pay a hundred staters; but if in another's fifty; and if with the wife of an apetairos, ten; but if a slave with a free woman, he shall pay double; and if a slave with a slave, five [8, p. 40]. 
By the laws of Hammurabi, a man is granted more by a privilege to declare divorce than a woman, but a woman with children can expect, first, returning her bridewealth and dowry or obtaining some shekels of silver if she had no bridewealth before, and, second, obtaining one half of the movable and immovable property ("her husband's field, orchard, and property"):

\$137 If a man should decide to divorce a šugìtu who bore him children, or a nadìtu who provided him with children, they shall return to that woman her dowry and they shall give her one half of (her husband's) field, orchard, and property, and she shall raise her children; after she has raised her children, they shall give her a share comparable in value to that of one heir from whatever properties are given to her sons, and a husband of her choice may marry her.

\$138 If a man intends to divorce his first-ranking wife who did not bear him children, he shall give her silver as much as was her bridewealth and restore to her the dowry that she brought from her father's house, and he shall divorce her.

\$139 If there is no bridewealth, he shall give her 60 shekels of silver as a divorce settlement.

\$140 If he is a commoner, he shall give her 20 shekels of silver.

\$141 If the wife of a man who is residing in the man's house should decide to leave, and she appropriates goods, squanders her household possessions, or disparages her husband, they shall charge and convict her; and if her husband should declare his intention to divorce her, then he shall divorce her; neither her travel expenses, nor her divorce settlement, nor anything else shall be given to her. If her husband should not declare his intention to divorce her, then her husband may marry another woman and that (first) woman shall reside in her husband's house as a slave woman.

\$142 If a woman repudiates her husband, and declares, "You will not have marital relations with me" - her circumstances shall be investigated by the authorities of her city quarter, and if she is circumspect and without fault, but her husband is wayward and disparages her greatly, that woman will not be subject to any penalty; she shall take her dowry and she shall depart for her father's house.

\$143 If she is not circumspect but is wayward, squanders her household possessions, and disparages her husband, they shall cast that woman into the water [5, p. $107-108]$.

Also, it is well expressed that the woman of the awilu-class can receive one half of the property produced by marriage:

\$176b If the woman of the awilu-class does not have a dowry, they shall divide into two parts everything that her husband and she accumulated subsequent to the time that they moved in together, and the slave's owner shall take half and the woman of the awilu-class shall take half for her children [5, p. 116].

In the Law Code of Gortyn, a woman after divorce can get her bridewealth and dowry back also and, additionally, she can receive one half of the property produced by marriage ("one half of the produce"), and she can carry away anything of the movable property ("anything else belonging to the husband") after paying five staters:

And if a husband and wife should be divorced, she is to have her own property which she came with to her husband and half of the produce, if there be any from her own property, and half of whatever she has woven within, whatever there may be, plus five staters if the husband be the cause of the divorce; but if the husband should declare that he is not the cause, the judge is to decide on oath. And if she 
should carry away anything else belonging to the husband, she shall pay five staters and whatever she may carry away; and let her restore whatever she may have filched; but as regards things which she denies (the judge) shall decree that the woman take an oath of denial by Artemis, before the statue of the Archeress in the Amyklaian temple [8, p. $40-41]$.

Hammurabi established a protection of children's inheritance and property rights after the death of their father or mother. In the meanwhile, it is affirmed that the dowry of the died and childless woman belongs only to her father's house:

\$177 If a widow whose children are still young should decide to enter another's house, she will not enter without (the prior approval of) the judges. When she enters another's house, the judges shall investigate the estate of her former husband, and they shall entrust the estate of her former husband to her later husband and to that woman, and they shall have them record a tablet (inventorying the estate). They shall safeguard the estate and they shall raise the young children; they will not sell the household goods. Any buyer who buys the household goods of the children of a widow shall forfeit his silver; the property shall revert to its owner [5, p. 116].

\$162 If a man marries a wife, she bears him children, and that woman then goes to her fate, her father shall have no claim to her dowry; her dowry belongs only to her children.

\$163 If a man marries a wife but she does not provide him with children, and that woman goes to her fate - if his father-in-law then returns to him the bridewealth that that man brought to his father-in-law's house, her husband shall have no claim to that woman's dowry; her dowry belongs only to her father's house [5, p. 112].

In the same way the inheritance and property rights of children after the death of their father or mother are protected in the Law Code of Gortyn, and the dowry of the died and childless woman is regarded also as belonging to her father's house:

If a man die leaving children, should the wife so desire, she may marry, holding her own property and whatever her husband might have given her according to what is written, in the presence of three adult free witnesses; but if she should take away anything belonging to the children, that becomes a matter for trial. And if he should leave her childless, she is to have her own property and half of whatever she has woven within and obtain her portion of the produce that is in the house along with the lawful heirs as well as whatever her husband may have given her as is written; but if she should take away anything else, that becomes a matter for trial. And if a wife should die childless, (the husband) is to return her property to the lawful heirs and the half of whatever she has woven within and the half of the produce, if it be from her own property $[8, \mathrm{p} .41]$.

If the husband or wife wish to make payments for porterage, (these should be) either clothing or twelve staters or something of the value of twelve staters, but not more. If a female serf be separated from a serf while he is alive or in case of his death, she is to have her own property; but if she should carry away anything else, that becomes a matter for trial. If a wife who is separated (by divorce) should bear a child, (they) are to bring it to the husband at his house in the presence of three witnesses; and if he should not receive it, the child shall be in the mother's power either to rear or expose; and the relatives and witnesses shall have preference in the oath as to whether they brought it. And if a female serf should bear a child while 
separated, (they) are to bring it to the master of the man who married her in the presence of two witnesses [8, p. 41].

In the Law Code of Hammurabi, the male children should divide their father and mother property after their death rather equally:

\$165 If a man awards by sealed contract a field, orchard, or house to his favorite heir, when the brothers divide the estate after the father goes to his fate, he (the favorite son) shall take the gift which the father gave to him and apart from that gift they shall equally divide the property of the paternal estate [5, p. 112].

\$167 If a man marries a wife and she bears him children, and later that woman goes to her fate, and after her death he marries another woman and she bears children, after which the father then goes to his fate, the children will not divide the estate according to the mothers; they shall take the dowries of their respective mothers and then equally divide the property of the paternal estate [5, p. 113].

$\$ \mathbf{\$ 1 7 0}<\ldots>$ After the father goes to his fate, the children of the first-ranking wife and the children of the slave woman shall equally divide the property of the paternal estate; the preferred heir is a son of the first-ranking wife, he shall select and take a share first.

\$171 But if the father during his lifetime should not declare to (or: concerning) the children whom the slave woman bore to him, "My children," after the father goes to his fate, the children of the slave woman will not divide the property of the paternal estate with the children of the first-ranking wife [5, p. 114].

\$173 If that woman should bear children to her latter husband into whose house she entered, after that woman dies, her former and latter children shall equally divide her dowry [5, p. 115].

The same rule holds in the Law Code of Gortyn to divide the inheritance equally among the male children first:

When a man or a woman dies, if there be children or children's children or children's children's children, they are to have the property. And if there be none of these, but brothers of the deceased and brothers' children or brothers' children's children, they are to have the property. And if there be none of these, but sisters of the deceased and sisters' children or sisters' children's children, they are to have the property. And if there be none of these, they are to take it up, to whom it may fall as source of the property [8, p. 43].

It is prohibited to sell the inheritance of children as well as the same is forbidden by Hammurabi:

As long as the father lives, no one shall offer to purchase any of the paternal property from a son nor take out a mortgage on it; but whatever (the son) himself may have acquired or inherited, let him sell, if he wishes. Nor shall the father sell or mortgage the possessions of his children, whatever they have themselves acquired or inherited. Nor shall the husband sell or pledge those of his wife, nor the son those of his mother. And if anyone should purchase or take on mortgage or accept a promise otherwise than is written in these writings, the property shall be in the power of the mother and the wife, and the one who sold or mortgaged or promised 
shall pay two-fold to the one who bought or accepted the mortgage or the promise and, if there be any other damage besides, the simple value; but in matters of previous date there shall be no ground for action. If, however, the defendant should maintain, with reference to the matter about which they contend, that it is not in the power of the mother or the wife, the action shall be brought where it belongs, before the judge where it is prescribed for each case. If a mother die leaving children, the father is to be in control of the mother's property, but he shall not sell or mortgage unless the children consent and are of age; but if anyone should otherwise purchase or take on mortgage, the property shall be in the power of the children and the seller or mortgagor shall pay twofold the value to the purchaser or mortgagee and, if there be any other damage besides, the simple value. And, if he should marry another woman, the children are to be in control of the mother's property [8, p. 44].

Also, it is prohibited to sell father's property before his death:

If a son has gone surety, while his father is living, he and the property which he possesses shall be subject to fine [8, p. 47].

The children born to a free woman and a slave man are considered free by the Greeks:

(If the slave) goes to a free woman and marries her, their children shall be free; but if the free woman goes to the slave, their children shall be slaves. And if free and slave children should be born of the same mother, in a case where the mother dies, if there is property, the free children are to have it; but if there should be no free children born of her, the heirs are to take it over [8, p. $44-45]$.

The same rule in respect to a woman of the awilu-class takes place in the Law Code of Hammurabi:

\$175 If a slave of the palace or a slave of a commoner marries a woman of the awilu-class and she then bears children, the owner of the slave will have no claims of slavery against the children of the woman of the awilu-class [5, p. 115].

In the Law Code of Gortyn, it is affirmed that money for investment in a partnership venture should be divided equally and any court has to protect this right:

If one has formed a partnership with another for a mercantile venture, in case he does not pay back the one who has contributed to the venture, if witnesses who are of age should testify - three in a case of a hundred staters or more, two in a case of less down to ten staters, one for still less - let (the judge) decide according to the testimony; but if witnesses should not testify, in case the contracting party comes, whichever course the complainant demands, either to deny on oath or $-[\ldots],[8, \mathrm{p}$. 47].

An appropriate right to benefit from investment is well emphasized by Hammurabi, too:

§gap cc If a man gives silver to another man for investment in a partnership venture, before the god they shall equally divide the profit or loss [5, p. 99].

§gap $\mathbf{z}$ If a man borrows grain or silver from a merchant and does not have grain or silver with which to repay but does have other goods, he shall give to his 
merchant in the presence of witnesses whatever he has at hand, in amounts according to the exchange value; the merchant will not object; he shall accept it [5, p. 99].

\$107 If a merchant entrusts silver to a trading agent and the trading agent then returns to his merchant everything that the merchant had given him but the merchant denies (having received) everything that the trading agent had given him, that trading agent shall bring charges and proof before the god and witnesses against the merchant, and because he denied the account of his trading agent, the merchant shall give to the trading agent sixfold the amount that he took [5, p. 101].

By Hammurabi, each man can adopt a child, then he cannot rear this child without an inheritance, but the child can seek his father and mother to return to his father's house:

\$185 If a man takes in adoption a young child at birth and then rears him, that rearling will not be reclaimed.

$\$ 186$ If a man takes in adoption a young child, and when he takes him, he (the child?) is seeking his father and mother, that rearling shall return to his father's house.

\$190 If a man should not reckon the young child whom he took and raised in adoption as equal with his children, that rearling shall return to his father's house [5, p. 119].

\$191 If a man establishes his household (by reckoning as equal with any future children) the young child whom he took and raised in adoption, but afterwards he has children (of his own) and then decides to disinherit the rearling, that young child will not depart empty-handed; the father who raised him shall give him a onethird share of his property as his inheritance and he shall depart; he will not give him any property from field, orchard, or house [5, p. $119-120]$.

The same situation in relation to adoption is observed in the Law Code of Gortyn:

Adoption may be made from whatever source anyone wishes. And the declaration of adoption shall be made in the place of assembly when the citizens are gathered, from the stone from which proclamations are made. And if he (the adopted person) should receive all the property and there should be no legitimate children besides, he must fulfill all the obligations of the adopter towards gods and men and receive as is written for legitimate children; but if he should not be willing to fulfill these obligations as is written, the next-of-kin shall have the property [8, p. 48].

$\langle\ldots\rangle$ but if the adopted son should die without leaving legitimate children, the property is to revert to the heirs of the adopter. And if the adopter wishes, he may renounce (the adopted son) in the place of assembly when the citizens are gathered, from the stone from which proclamations are made; and he shall deposit ten staters with the court, and the secretary (of the magistrate) who is concerned with strangers shall pay it to the person renounced; but a woman shall not adopt nor a person under puberty [8, p. 49].

Thus, as we see, the only Greek law code, preserved until today, has evidently Semitic roots. Most probably, there was a direct Phoenician influence on establishing the Greek legal tradition. In any case, the Greeks knew deductions and other logical inferring within legal proceedings from a Semitic legal culture grown up, in turn, from the Akkadian Law Code of Hammurabi and other Old Babylonian codes. 


\section{Inference Rules in Trial Records}

There are the following two most significant inference rules in Babylonian legal proceedings: modus ponens and modus tollens. They seem to us an evident tool in inferring. However, they are not so evident and easy even for philosophers. For example, one of the earliest "logical" treatises in India is represented by the Kathāvatthu, belonging to the Abhidhammapitaka of the Pāli Canon. It is a compendium of logical reasoning based, only at the first glance, on modus ponens and modus tollens. In reality, its author does not know how to infer logically by using modus ponens and modus tollens.

Let us consider an example from the Kathāvatthu consisting of debates between a Theravādin and non-Theravādins. One of these debates can be formalized as follows:

Theravādin.-Is A B?

Puggalavādin.-Yes.

Ther.-Is A C?

Pugg.-No.

Ther.-However, 'if A is B, then A is C.' Then that which you say here is wrong, because you state that ' $A$ is $B$ ' is true, but ' $A$ is $C$ ' is false. But if ' $A$ is $C$ ' is false, then ' $\mathrm{A}$ is $\mathrm{B}$ ' is false.

Symbolically, it is a modification of modus tollens:

$(A \Rightarrow B) \Rightarrow(A \Rightarrow C) ; \neg(A \Rightarrow C)$

$\neg(A \Rightarrow B)$.

So, the latter flow chart seems to be correct. But it is not, because the Theravādin believes that $A \Rightarrow B$ is false, while $A \Rightarrow C$ is true, and the Puggalavādin believes that $A \Rightarrow B$ is true, while $A$ $\Rightarrow C$ is false. Hence, we face a sophism, not modus tollens: the Theravādin puts forward two premises, the first of them $[(A \Rightarrow B) \Rightarrow(A \Rightarrow C)]$ is not valid, because its antecedent is false, and the second of them $[\neg(A \Rightarrow C)]$ is false [namely, $A \Rightarrow C$ is true, so $\neg(A \Rightarrow C)$ is false], therefore the conclusion $[\neg(A \Rightarrow B)]$ cannot be inferred at all.

Thus, the author of the Kathāvatthu does not know logic. Only one book of the Pāli Canon contains modus ponens and modus tollens with their logically correct applications. It is the Milindapañha written in Gandhāra at the time of the Greek rule and dated to from the $1^{\text {st }}$ century B.C. to the $1^{\text {st }}$ century A.D.

Among the Greek philosophers Chrysippus was first who correctly and explicitly defined modus ponens and modus tollens. His samples:

(i) modus ponens: "If it is day, it is light; but in fact it is day; therefore it is light" (Sextus Empiricus, Against the Logicians II, 224);

(ii) modus tollens: "If it is day, it is light; but it is not light; therefore it is not day" (Sextus Empiricus, Against the Logicians II, 225).

We do not know whether Chrysippus applied his propositional logic in a legal hermeneutics. But his prominent Roman follower, Marcus Tullius Cicero (106 - 43 B.C.), did it really well. Cicero wrote the Topica where he showed how we can use the loci (logical frameworks, Latin: "places") to draw out the consequences from legal propositions. His Topica is a unique sample of applying a symbolic logic in the Roman-Greek legal hermeneutics (see the commentary by Tobias Reinhardt in [3]). Cicero distinguishes 'invention' and 'judgment.' According to him, 'invention' is a logical investigation of differences among particulars and generals to introduce new concepts, and 
'judgment' is a compendium of logical tools for reaching correct and true conclusions from different true propositions. By Cicero, Aristotle developed a system for both 'invention' and 'judgment,' but Chrysippus proposed a system just for 'judgment.' Cicero in his Topica tries to combine both approaches, i.e. the Aristotelian and Stoic ones:

6 Cum omnis ratio diligens disserendi duas habeat artes, unam inveniendi alteram iudicandi, utriusque princeps, ut mihi quidem videtur, Aristoteles fuit. Stoici autem in altera elaboraverunt; iudicandi enim vias diligenter persecuti sunt ea scientia

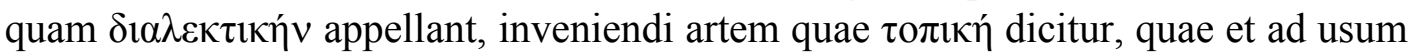
potior erat et ordine naturae certe prior, totam reliquerunt. 7 Nos autem, quoniam in utraque summa utilitas est et utramque, si erit otium, persequi cogitamus, ab ea quae prior est ordiemur. Ut igitur earum rerum quae absconditae sunt demonstrato et notato loco facilis inventio est, sic cum pervestigare argumentum aliquod volumus, locos nosse debemus; sic enim appellatae ab Aristotele sunt eae quasi sedes, e quibus argumenta promuntur. 8 Itaque licet definire locum esse argumenti sedem, argumentum autem rationem quae rei dubiae faciat fidem.

All methodical treatment of rational discourse involves two skills, invention and judgement; Aristotle came first in both, it seems to me. The Stoics on the other hand concerned themselves with one of the two skills only; that is, they pursued ways of judging (arguments) diligently by means of that science which they call dialectic. The skill of invention, however, which is called topice and which was both of more immediate practical use and certainly prior in the order of nature, they completely neglected. But since both skills are of the utmost usefulness and since we intend to pursue both, if time allows we shall begin with that which is prior. Just as it is easy to find hidden things, once their hiding-place has been pointed out and marked down, so we need to know the right Places if we wish to track down a certain argument; 'Places' [A.Sch.-loci in Latin and tó $\pi$ or in Greek] is the name Aristotle gave those locations, so to speak, from which we can draw arguments. Therefore we may define a Place as the location of an argument, and an argument as a reasoning that lends belief to a doubtful issue [3, p. 119].

An example of inferring from a general considered by Cicero is as follows:

13 A genere sic ducitur: Quoniam argentum omne mulieri legatum est, non potest ea pecunia quae numerata domi relicta est non esse legata; forma enim a genere, quoad suum nomen retinet, numquam seiungitur; numerata autem pecunia nomen argenti retinet; legata igitur videtur.

From the genus an argument is derived as follows: Since all the silver was bequeathed to the woman, it cannot be the case that the money which remained at home in form of coins was not bequeathed; for the species is never dissociated from the genus, as long as it retains its name; but money in form of coins retains the name 'silver'; therefore, it seems to have been bequeathed [3, p. 123].

One of the main features of law codes regarded by Cicero is a full enumeration of particulars $A_{1}, A_{2}, \ldots, A_{n}$, related to one general $B$, i.e. a full list of implications $A_{1} \Rightarrow B, A_{2} \Rightarrow B, \ldots, A_{n} \Rightarrow B$ with the same $B$, as it was supposed in any law code. These $A_{1}, A_{2}, \ldots, A_{n}$ should be exclusive. It means that they should be connected by strong disjunctions "either ... or ..." (Akkadian: " $\bar{u} l$... $\bar{u} l . . . "$, symbolically: “... $\otimes . .$.$) . In this case there is the following equivalence: \left(A_{1} \otimes A_{2} \otimes \ldots \otimes\right.$ $\left.A_{n}\right) \Leftrightarrow B$. From this we can draw the following conclusion: 
$A_{1} \Rightarrow B ; A_{2} \Rightarrow B ; \ldots ; \quad A_{n} \Rightarrow B ; \quad C \Rightarrow \neg A_{1} ; C \Rightarrow \neg A_{2} ; \ldots ; C \Rightarrow \neg A_{n}$

$\left(A_{1} \otimes A_{2} \otimes \ldots \otimes A_{n}\right) \Rightarrow B ; \quad C \Rightarrow \neg\left(A_{1} \otimes A_{2} \otimes \ldots \otimes A_{n}\right)$

$C \Rightarrow \neg B$

Cicero formulates this rule thus:

Tum partium enumeratio quae tractatur hoc modo: Si neque censu nec vindicta nec testamento liber factus est, non est liber; neque ulla est earum rerum; non est igitur liber.

Next, the enumeration of the parts (sc. of the whole), which is handled in the following way: If someone has not been freed by either having his name entered in the census-roll or by being touched with the rod or by a provision in a will, then he is not free. None of these applies to the individual in question. Therefore he is not free $[3$, p. 121].

This logical rule implemented in any code may be named a completeness of legal information. This completeness means that if we take any factual verified case $C$ of an indictment, then for any general $B$ from the code, each court can announce either a verdict $C \Rightarrow B$ or a verdict $C$ $\Rightarrow \neg B$ inferred from the code just logically.

Thus, each article of the code is formulated in the form of implication: "If/when (Sumerian: tukum-bi) this or that occurs $(A)$, this or that must be done $(B)$," i.e. $A \Rightarrow B$. Among different particulars $A_{1}, A_{2}, \ldots, A_{n}$, implying generals $B_{1}, B_{2}, \ldots, B_{k}$ there are some labels such as classes of personalities, e.g. some classes of people from the Laws of Ur-Nammu (ca. 2047 - 2030 B.C., Ur) are as follows: 'a free man' (Sumerian: lî), 'a wife' (Sumerian: dam), 'the first-ranking wife' (Sumerian: nitadam), 'the native-born woman' (Sumerian: dumu-gi $i_{7}$ ), 'the widow' (Sumerian: numasu), 'a young man' (Sumerian: guruš), 'a male slave' (Sumerian: arad), and 'a female slave' (Sumerian: géme). These labels allow us to define whether our case $C$ at a court corresponds to one of the particulars $A_{1}, A_{2}, \ldots, A_{n}$ or not. And due to this correspondence to one of $A_{1}, A_{2}, \ldots, A_{n}$, we can infer either a verdict $C \Rightarrow B_{i}$ or a verdict $C \Rightarrow \neg B_{i}$ for each general $B_{i}$.

In the Babylonian legal tradition, the law code must have been published at the beginning as a main source for legality. This publication was marked by erecting a stele with official inscriptions or by engraving these inscriptions on a wall. One of the best-known steles with such inscriptions belongs to Hammurabi and represents his laws cited above. Another example may be provided with the inscriptions on the wall in the agora of Gortyn representing the Greek law code cited above, too.

The law code was considered a set of axioms announced for all due to its publications on a stone. To the same extent, the Tables of the Law (Hebrew: לוחות הברית) inscribed, according to the Torah, by God were official inscriptions of the Judaic law code written on stones:

And He gave unto Moses, when He had made an end of speaking with him upon mount Sinai, the two tables of the testimony, tables of stone, written with the finger of God (Exodus 31:18).

In the Samaritan Pentateuch it is stated more explicitly that the Israelites should have write down their code on stones:

14a And when Shehmaa your Eloowwem will bring you to the land of the Kaanannee which you are going to inherit it. 14b You shall set yourself up great stones and lime them with lime. And you shall write on them all the words of this law.14C And when you have passed over the Yaardaan you shall set up these 
stones, which I command you today, in Aargaareezem. 14d And there you shall build an altar to Shehmaa your Eloowwem, an altar of stones, you shall lift up no iron on them (Exodus 20:14, the Samaritan Pentateuch, translated by Benyamim Tsedaka).

This fragment is quite unique, because it is absent from the Hebrew Bible. The Tables of the Law were regarded here as made by human beings and put into the wall at the temple of mount Gerizim ('Aargaareezem'). Among other Semitic peoples it was a usual practice to write basic rules on stones for a public announcement of the law code.

We can assume that all the Semitic cultures directly influenced by the Akkadians had a kind of law code, even if this code was not preserved till now. For instance, we have no fragments of the Old Assyrian law code at all, but a publication of this code on stones is cited many times in some judicial records and letters, containing official verdicts, by references to "the words of the stele" (awāt naruāim), see for the details in [9]. In Akkadian a stele with laws was called narûm (Akkadian: "inscribed stone"). In Old Babylonian texts, 'a stele' is mentioned, for instance, in the following manner: "[F]or the shortfall which occurs one will treat him in accordance with the text of the stele (kima pi narim)" [9, p. 1721]. In Old Assyrian fragments, an appropriate mention is as follows: "To swear him with/by the three words of (variant: which are written on) the stele" [9, $\mathrm{p}$. 1721] and "The creditors of Šukubum, from whatever Šukubum possesses, in accordance with the words of the stele, when it is confirmed by witnesses, (each) will take his silver in/at/from/by means of his ..." [9, p. 1729].

According to the Neo-Babylonian cuneiform records (see [2]), we know that there existed a complex institution of royal judges (dayyānū ša šarri) who must have been experts in inferring trial verdicts from 'the words of the stele' just by deductions. The royal judges were organized in a bureaucratic hierarchy overseen by royal officials called sartennu or sukallu. The highest level in trial judgments was presented by 'the king's court of law' (bìt dīni ša šarri). In the Babylonian society, even the king was regarded as subject to the law. So, the royal judges were examined as social elite and, e.g., they were not removed from office when the king changed. Usually, each court consists of two judges, one of them handles a case and the second serves as a scribe/secretary.

Let us consider an example of trial. In the Law Code of Hammurabi there is the following rule:

\$8 If a man steals an ox, a sheep, a donkey, a pig, or a boat - if it belongs either to the god or to the palace, he shall give thirtyfold; if it belongs to a commoner, he shall replace it tenfold; if the thief does not have anything to give, he shall be killed [5, p. 82].

For instance, "If a man steals $X$ sheep and it belongs to the god (to an appropriate temple), then he must replace it thirtyfold (i.e. the amount of $X \cdot 30) . "$

There is a trial record denoted YBC 3771, found in Uruk, and dated to 12.XII.3 Camb (22 March, 526 B.C.), see [2, p. 178 - 181]. In this trial record, two judges determine that Bēl-iqī̌sa, who led away 5 sheep belonging to 'Ištar of Uruk and Nanaya' (a temple), must repay 155 sheep to the property of this temple, because 150 sheep is the thirtyfold penalty for five branded sheep and the five unbranded lambs are supposed to be born after steeling:

(1-6) [1 ram 4 ewes] total 5 sheep branded with a star and 5 unblemished lambs, a total of 10 sheep, property of Ištar of Uruk and Nanaya, from the pen of Anu-šarraușur son of Šarrukīn, which in Arahšamna, year 2 of Cambyses, king of Babylon, king of the lands, Bēl-iqīša son of Șillaya led away (in payment) from Anušarraușur son of Šarru-kīn. 
(7-11) In Addaru, year 3, Rīmūt and Bau-ēreš, the judges, wrote in a tablet and determined for Bēl-iqǐša to pay 150 sheep, thirtyfold for the sheep branded for Ištar and 5 unbranded lambs, a total of 155 sheep, for repayment to Ištar of Uruk. (12-14) On 25 Addaru, year 3, Bēliqī̌sa son of Șillaya shall bring these 155 sheep, brand them in the Eanna and give them to the property of the Eanna.

(14-16) Arad-Nergal son of Mukinnapli descendant of Egibi assumes responsibility for the repayment of these 155 sheep.

(16-17) In the presence of Nabûmukinn-apli, the šatammu of the Eanna, son of Nādinu descendant of Dābibī;

(18) Nabû-aha-iddin, the royal official in charge of the Eanna.

(19) Witnesses: Arad-Marduk, son of Zēriya descendant of Egibi;

(20) Sîn-ēreš son of Nabû-šumu-līšir descendant of Ibni-ili;

(21) Bēl-nādin-apli son of Mardukšuma-iddin descendant of Bēl-aplaușur;

(22) Nādinu, the scribe, descendant of Egibi;

(23) Arad-Marduk, the scribe, descendant of Bēl-apla-ușur.

(24-25) Uruk. 12 Addaru, year 3 of Cambyses, king of Babylon, king of the lands [2, p. $179-181]$.

This trial record is symbolically represented as an inference by modus ponens as follows:

1. If a man steals $X$ sheep and it belongs to the god (to a temple), then he must replace it thirtyfold (i.e. the amount of $X \cdot 30$ ) [the axiom from the code];

2. Ištar of Uruk and Nanaya is a temple [it is a fact, because 'a temple' is a generalization for the case of 'Ištar of Uruk and Nanaya'];

3. Bēl-iqī̌sa son of Șillaya led away 5 sheep belonging to Ištar of Uruk and Nanaya [the fact established by the trial];

Then, Bēl-iqīša son of Șillaya must repay 150 sheep to Ištar of Uruk and Nanaya on 25 Addaru, year 3.

Another example of trial record is denoted BM 46660 (see [2, p. 43 - 44]) and tells us that Marduk-šarranu has accused Kīnaya of striking his son and, as a result, two siblings, a brother and a sister, guarantee that Kinnaya will appear at the court. If Kinnaya escapes, then the two must pay compensation to Marduk-šarranu:

10'. A-šú ̌́á $m B A-\check{s} a ́-a n a-[\check{s} u-u k i-i]$

11'. mki-na-a ih-te-[li-qu]

12'. ZI.MEŠ šá DUMU-šú sa2 md[AMAR.UTU-LUGAL-a-nu]

13'. mdNA3-NUMUN-MU u fiș-[șur]-[

14'. ú-šal-lim-mu lu2mu-kin-nu m[PN

(10'-14') If Kīnaya escapes, Nabûzēra-iddin and Ișșur-[X] will pay compensation for the life of the son of Marduk-šarranu.

(14'-15') Witnesses: PN

[2, p. 44].

Symbolically:

1. If a man strikes somebody, then he must pay compensation [the axiom from the code];

2. If a man cannot pay, his guarantors must pay [the axiom from the code];

3. Kīnaya struck Marduk-šarranu's son [the proven fact]; 
4. If Kìnaya appears at the trial, he must pay compensation to Marduk-šarranu [the first conditional verdict];

5. If Kīnaya escapes, his two guarantors must pay compensation to Marduk-šarranu [the second conditional verdict];

Then, either Kīnaya or his two guarantors must pay compensation to Mardukšarranu.

The next instance of conditional verdicts is taken from the text denoted BM 31162, found in Opis, and dated to 23.VIII.40 Nbk (5 November, 565 B.C.), see [2, p. 45 - 47]. In this trial record, Gudaya, the guarantor of a grain loan to Katimu', testifies that he presented Katimu' to Bau-ēreš (the creditor) to repay the debt. Bau-ēreš has pressed the charges that he has not been repaid by Katimu'. Gudaya must present two witnesses now. If Gudaya finds these witnesses for his claim, then he is clear. If Gudaya does not support his statement by witnessing, then Gudaya must repay the barley and the interest to Bau-ēreš:

(1-9) By 1 Kislīmu, Gudaya son of Hinni-ilī shall bring two mār banî (as) his witnesses to Opis and establish, against Bau-ēreš son of Nabû-bāniahi, that, at the time (of the termination of the loan), Gudaya brought Katimu' son of Hagūru - for whose presence he (Gudaya) assumed guarantee to Bau-ēreš - to him (Bau-ēreš) and handed (Katimu') over to Bau-ēreš.

(10) If he (Gudaya) establishes (the case) against him (Bau-ēreš), he (Gudaya) is clear.

(11-12) If he (Gudaya) does not establish (the case) against him (Bauēreš), then he (Gudaya) shall pay Bauēreš barley and its interest according to the debt-note.

(13-14) Witnesses: Silim-Bēl son of Balāṭu;

(14-15) Iddin-Marduk son of Nabûittiya;

(15-16) and the scribe: Nabû-ahhēeiddin son of Šulaya descendant of Egibi.

(16-18) Opis. 23 Arahšamna, year 40 of Nebuchadnezzar, king of Babylon [2, p. 46].

Formally:

1. If a man takes a loan, he must repay the debt according to the debt-note in the presence of a guarantor [the axiom from the code];

2. If a man cannot pay, his guarantors must pay [the axiom from the code];

3. Gudaya son of Hinni-ilī was a guarantor that Katimu' took a loan from Bau-ēreš [the documented fact];

4. If Gudaya has two witnesses that he presented Katimu' to Bau-ēreš to repay the debt, Gudaya is free [the first conditional verdict];

5. If Gudaya has no witnesses that he presented Katimu' to Bau-ēreš, Gudaya must pay Bauēreš barley and its interest according to the debt-note [the second conditional verdict];

Then, either Gudaya is free or he must pay.

Usually, any relationship between creditors and debtors was regulated by a legal proceeding that may be formalized as follows:

1. The creditor $(C)$ has pressed the charges that the debtor $(D)$ has not given back the $X$ shekels taken from him. 
2. This $D$ is testifying at the trial: "The $X$ shekels of $C$ which I owed, I have paid to him in the presence of two witnesses: $W_{1}$ and $W_{2}$." In accordance with the words of the stele, it means that $D$ is free.

3. If his witnesses $W_{1}$ and $W_{2}$ are confirming: " $D$ has repaid the $X$ shekels to $C$," then $D$ must swear together with his witnesses and $D$ is free and $C$ forfeits his claims.

4. And if $D$ 's witnesses do not confirm $D$ 's statement, $C$ must swear together with his witnesses $W_{3}$ and $W_{4}$ that $D$ has taken the $X$ shekels from $C$ in the presence of $W_{3}$ and $W_{4}$ and $D$ must pay $C$ 's money back."

This legal proceeding has the following logical structure:

1. If a man takes a loan, he must do it in the presence of two witnesses $W_{3}$ and $W_{4}$ [the axiom from the code];

2. If a man took a loan in the presence of two witnesses $W_{3}$ and $W_{4}$, he must repay the debt [the axiom from the code];

3. If a man repays the debt, he must do it in the presence of two witnesses $W_{1}$ and $W_{2}$ [the axiom from the code];

4. If a man repays the debt in the presence of two witnesses $W_{1}$ and $W_{2}$, he is free [the axiom from the code];

5. There are two witnesses $W_{3}$ and $W_{4}$ that a debtor took a loan from a creditor [a documented fact];

Then, either the debtor must repay the debt or if he repaid it in the presence of two witnesses $W_{1}$ and $W_{2}$, then he is free.

Thus, each Neo-Babylonian trial record was a sophisticated syllogism, correctly constructed and based on true premises which are taken from the law code or verified by royal judges as documented facts.

To sum up, we can conclude as follows:

1. Drawing true and correct conclusions is not so easy and even philosophers can make mistakes or do not know how to infer at all. For example, the early Buddhist philosophers, such as the author of the Kathāvatthu, did not know correct forms of modus ponens and modus tollens and appealed just to sophisms.

2. Chrysippus was the first Greek philosopher who proposed a logical theory of inferring grounded on modus ponens and modus tollens. Cicero, the follower of Chrysippus, showed in his Topica that this theory is fundamental for the legal hermeneutics.

3. The logical analysis of Neo-Babylonian trial records allows us to affirm that the logical theory of conclusions based on modus ponens and modus tollens was established much earlier than it was done by Chrysippus; namely, this theory became a part of the Babylonian legal proceedings since the Sumerians.

\section{Conclusions}

In this paper, I have shown that symbolic logic was founded by the Sumerians and Akkadians within the legal tradition of the law codes. So, symbolic logic developed simultaneously with the legality.

\section{References}

1. Burrow, T. A Translation of the Kharosthi Documents from Chinese Turkestan. James G. Forlong Fund, Vol. XX. London: The Royal Asiatic Society, 1940. 
2. Holtz, Shalom E. Neo-Babylonian Trial Records. Society of Biblical Literature Atlanta, 2014.

3. M. Tulli Ciceronis. Topica. Edited with a translation introduction, and commentary by Tobias Reinhardt. Oxford University Press, 2003.

4. Mukherjee, B.N. The Great Kushana Testament, Indian Museum Bulletin, Calcutta, 1995.

5. Roth, M. T. Law collections from Mesopotamia and Asia Minor. With a contribution by Harry A. Hoffner, Ir.; edited by Piotr Michalowski. Scholars Press Atlanta, Georgia. 1995.

6. Sims-Williams, N., and Cribb, J. A New Bactrian Inscription of Kanishka the Great, Silk Road Art and Archaeology. Volume 4, 1996, pp. 75 - 142.

7. Thapar, R. Aśoka and the Decline of the Mauryas. Delhi: Oxford University Press, 1997.

8. The Law Code of Gortyn. Edited by Willetts, Ronald F. De Gruyter, 1967, pp. 37 - 50.

9. Veenhof, Klaas R. In Accordance with the Words of the Stele: Evidence for Old Assyrian Legislation, Chicago-Kent Law Review. Volume 70, Issue 4, 1995, pp. 1717 - 1744. 